\title{
Scriptures outside the Book
}

\section{$1 \quad$ Reformed Identity between Book and Reading}

This section presents an overview of the different institutional offerings and resources that are focused on DH and biblical studies or theology, such as the Master's Degree in Digital Theology and Biblical Studies that is offered at both Durham University (UK) and Vrije University (Amsterdam, NL)' ; a theology DH Center like CoDEC ${ }^{2}$ is another example. Brill, meanwhile, has started a series entitled Digital Biblical Studies ${ }^{3}$. Diverse DH research groups now also exist such as the Bible, Early Jewish and Christian Studies at the SBL, ISBL and EABS. The first monograph on the Bible in digital culture was published by Jeffrey Siker in $2017^{4}$.

Such innovations clearly question Christian theology, particularly the Reformed confession for which the Scriptures are of primary importance, according to the Reformed theologian Pierre Gisel: "the Scripture stands at the place of origin, whereas it is a secondary phenomenon historically speaking"5. The celebration of the 5ooth birthday of the Reformation presented an opportunity to revisit the Scriptures as a topic in Protestant Churches ${ }^{6}$. In 2016, the Federation of Swiss Protestant Churches (FSPC) published a commemorative study entitled not sola scriptura, but Sola lectura? in both German and French versions.

The French translation differs slightly from the German version in its representation of the digital turn's impact on Scripture. Indeed, the German version refers to the "emancipation" of writing from the confines of books, whereas the French version defines it as a "dissociation" between writing and books: "a new question is raised today: the signification, for the concrete expression of the Christian faith, of the emancipation of writing from the book (die Emanzipa-

1 MA in Digital Theology, Durham, <https://www.dur.ac.uk/codec/courses/>; MA in Biblical Studies and Digital Humanities, Vrije Amsterdam University, <http://www.godgeleerdheid. vu.nl/nl/Images/BiblicalStudies_tcm238-829352.pdf>.

2 CODEC center, Durham University, <https://www.dur.ac.uk/codec/ $>$.

3 Digital Biblical Studies, Brill, <https://brill.com/DBS>.

4 Siker, Liquid Scripture.

5 Gisel, "Apocryphes et canon", p. 230: "l'Ecriture occupe le lieu de l'origine, tout en étant un phénomène historiquement second".

6 The journal Zeitschrift des Neuen Testaments 39/40 (2017) is a double issue entirely devoted to the Reformation birthday and the sola scriptura. 
tion der Schrift vom Buch, la dissociation entre l'écrit et le livre), with its prolongation in the continued presence of writing in all kinds of electronic media"7.

Emancipation or dissociation: these two words clearly illustrate the ambiguity of the Reformed confession in the face of the digital turn. Such a duality is of course present in general intellectual discourse: the philosopher Umberto Eco stated in 2011 that we were facing a turn "worse than the fall of the Roman Empire". This stands in contrast to another philosopher, Michel Serres, who stated that we were experiencing "the rebirth of humankind" $(2013)^{8}$. The divergence here is greater than the contrast between emancipation and dissociation. Given the cultural challenges of the current era, the Reformed tradition should hear voices not bound by a fascination with books. In a short but clear video, the Reformed theologian Karl Barth explains the process of writing his commentary on the Roman Epistle: he did not want to "write a book" but rather to reach an "imperceptible community", unsichtbare Gemeinschaft ${ }^{9}$ the purpose of communication thus determines the perception of digital writing.

\section{Scriptures and Digital Culture: History and Materiality}

In his recent monograph Un fantôme dans la bibliothèque, the French writer Markus Olender underlines the relationship between writing material, the archive and Christianity - designating the archive as a "form of the Christian civilisation"10. Such a statement lends credence to a 2011 hypothesis: we are seemingly leaving the Christian Era behind, a label that was created when printed culture emerged ${ }^{11}$. The links that Olender weaves between writing materials and thinking forms are in line with the writings of Goody, Chartier and Vandendorpe ${ }^{12}$.

7 SEK, Sola lectura? Aktuelle Herausforderungen, p. 10; FE PS, Sola lectura?, p. 30: "Une question nouvelle se pose aujourd'hui: celle de la signification, pour l'expression concrète de la foi chrétienne, de la dissociation entre l'écrit et le livre, avec son prolongement dans l'omniprésence de l'écrit dans les médias électroniques de toutes sortes".

8 Eco, "Vers une nouvelle Renaissance", p. $5^{2}$; Cabé, "Michel Serres", <http://www.lavie.fr/ actualite/societe/michel-serres-nous-sommes-face-a-une-renaissance-de-l-human ite-16-05-2013-40284_7.php>.

9 Barth, "Karl Barth \& the Epistle to the Romans", <https://vimeo.com/90346827>.

10 Olender, Unfantôme, p. 80.

11 Clivaz, "Common Era", p. 36-40.

12 Clivaz, "Common Era", p. 33-36 and 51. 
Olender alerts readers to three major risks he perceives in digital culture: digital memory loss ${ }^{13}$, the rise of fake news in an "unintelligent world"14, and the strangeness of digital "material immaterial documents"15. The second part this chapter considers Olender's concerns by underlining the importance of gaining an in-depth knowledge regarding digital writing and coding in particular. Indeed, Humanists should be attentive to electronic language as language in itself. As Domenico Fiormonte states : "each act of encoding, or rather each act of representation of the specific 'object' via a formal language involves a selection from a set of possibilities and is therefore an interpretative act"16. With respect to the feelings one might develop by being in contact with "material immaterial documents", this section presents Derrida's point of view on what it means to leave paper behind when it is so profoundly related to our body ${ }^{17}$. The relationships between bodies and writing materials are numerous: these will be covered in Chapters 3 and 4 . The Christian tradition is notably rich in such examples, including Lyotard, who in a posthumous volume, compares a book to skin, based on Rev 6,14 and Augustine ${ }^{18}$.

This section develops examples of religious perceptions and vocabulary used in digital culture: examples such as the $c l o u d^{19}$ and the simple creation of the French word ordinateur by the Sorbonne professor Jacques Perret ${ }^{20}$. It is therefore natural to return to one of the important roots of crosspollination between religion and digital humanities, the Jesuit Roberto Busa. He is often perceived as the father of $\mathrm{DH}$, for example according to Domenico Fiormonte: "Busa's undertaking founded the discipline of the Humanities Computing (although years later it was renamed Digital Humanities), but above all it laid the groundwork for a profound epistemological and cultural transformation" 21 . However, other scholarly voices have undertaken historical inquiries that point to the more complex reality of the birth of $\mathrm{DH}^{22}$.

\footnotetext{
13 Olender, Un fantôme, p. 65.

14 Olender, Un fantôme, p. 190-192.

15 Olender, Un fantôme, p. 28.

16 Fiormonte, “The Digital Humanities", p. 30.

17 Derrida, “Le papier et moi”, p. 46.

18 Lyotard, La Confession d'Augustin, p. 59.

19 See Shep, "Digital Materiality”, Kindle, l. 10861-11168.

20 Nieuwbourg, "Découvrez l'origine”, <http://blog.museeinformatique.fr/Decouvrez-l-ori gine-du-mot-ordinateur-invente-il-y-a-pres-de-55-ans-par-Jacques-Perret-a-la-demandede-IBM_a212.html>. Last accessed on 18.07.18.

21 Fiormonte, "The Digital Humanities", p. 30.

22 See notably Jones, Roberto Busa; Nyhan - Flinn, Computation and the Humanities.
} 
With respect to the Bible, it should be noted that Busa never focused on $\mathrm{it}^{23}$ explicitly, whereas the first digital tool for the Bible was created by Reverend John W. Ellison: while Busa was busy producing the digital Index of Thomas Aquinus, Ellison prepared an index of the English translation of the Bible known as the Revised Standard Version ${ }^{24}$. It is worth revisiting the roots and heritage of Digital Humanities. Chapter 2 does exactly this by following the French thinker Milad Doueihi's suggestion: such an inquiry should begin with Alan Turing's article, "Computing Machinery and Intelligence" 25.

\section{Towards Digital Scriptures: Critical Editing and Multimodal Literacy}

The publishing of the Greek New Testament is a process undergoing significant evolution in digital culture, and this change has been noted since $2011^{26}$. In 2008, David Parker already had predicted a "drastic change"27 for NTTC with the emergence of digital culture. The main actors of NTTC are the Institute for the New Testament Textual Research (INTF), the Institute for Textual Scholarship and Electronic Editing (ITSEE, Birmingham) and the International Greek New Testament Project (IGNTP) that is in charge of editing the Editio Critica Major ${ }^{28}$. Developments such as the New Testament Virtual Manuscript Room $^{29}$ are progressively introducing digital culture and new ways of conceiving NT publication. New elements clearly make the domain richer and more complex, such as the development of NT manuscript websites like PAVONe $e^{30}$ focused on the Arabic NT manuscripts, or new Greek NT versions such as the 2017 Tyndale House Greek New Testament (THGNT) by Dirk Jongkind, Peter Head and Peter Williams ${ }^{31}$.

These developments raise the question of the potential loss of the canonicity of these Scriptures, this is debated in Chapter $4^{32}$. Before the rise of digital

\footnotetext{
23 Jones, Roberto Busa, p. 126.

24 Jones, Roberto Busa, p. 100-101.

25 Turing, "Computing Machinery and Intelligence", <http://www.phil415.pbworks.com/f/ TuringComputing.pdf>.

26 Clivaz, "The New Testament at the Time of the Egyptian Papyri".

27 Parker, An introduction to the New Testament, p. 1.

28 ECM. The Editio Critica Major, <https://www.uni-muenster.de/INTF/ECM.html>.

29 INTF \& ITSEE, New Testament Virtual Manuscript Room, <http://ntvmr.uni-muenster. de $/>$.

30 Pavone, Platform of the Arabic Versions of the New Testament, <http://pavone.uob-dh. $\operatorname{org} />$.

$31 \quad$ Jongkind - Head - Williams (ed.), Tyndale House Greek New Testament.

$3^{2}$ See Chapter 4, point 2.
} 
scholarship, there was already an impression that the pages of the Scriptures were leaving books. In 1998, scriptura in koinonia was proposed as a point of consideration due to the growing scholarly interest in apocryphal literature ${ }^{33}$. Twenty years later, in the FSPC report, Sola lectura? demonstrates that the sola scriptura is indeed searching for new paths ${ }^{34}$ in the direction of the unsichtbare Gemeinschaft described by Karl Barth ${ }^{35}$. The question of writing material also impacts the issue profoundly, as demonstrated in a 2016 study $^{36}$. Consequently, Chapter 4 will attempt to draft potential scenarios for these Scriptures "outside the book", or the "body of Scriptures" apart from the book. This follows on from Chapter 3 which highlights the new relationship between writing and the body. Chapters 3 and 4 will thus illustrate and demonstrate Derrida's proposal: new technologies point to new relationships between human bodies and machines ${ }^{37}$.

Furthermore, Chapters 3 and 4 will develop the multimodal aspect of writing and consequently digital Scriptures. Biblical exegesis is increasingly attentive to orality, notably with the emergence of performance criticism ${ }^{38}$ and visuality, as Robbins and Melion point out in their 2017 book: Art Visual Exegesis: Rhetoric, Texts, Images ${ }^{39}$. However, the main multimodal impact on Scriptures is due to the widespread use of biblical applications. The two main applications are YouVersion and GloBible ${ }^{40}$, promoted by evangelical trends according to the analysis of Tim Hutchings ${ }^{41}$.

The creation of multimodal digital expressions of the Scriptures addresses several new theological challenges, from exegesis to practical theology, and from ethics to systematic theology. Given such a cultural context, the affirmation that "the Scripture stands at the place of origin" 42 is consequently ever less evident. In attempting to hold together the text of these Scriptures, the attention of Christian communities is drawn towards unsichtbare Gemeinschaft, towards people as receptacles of written texts. This is exactly what is illustrated by Ray Bradbury in the 1953 novel Fahrenheit $45^{43}$.

\footnotetext{
33 Clivaz, "La troisième quête du Jésus historique", p. 557.

34 See SEK, Sola lectura?, p. 10.

35 Barth, "Karl Barth \& the Epistle to the Romans", <https://vimeo.com/90346827>.

36 Clivaz, "Categories of Ancient Christian texts and writing materials".

37 Derrida, Sur parole, Kindle, 1. 484.

38 Oestreich - Holland, Performance Criticism of the Pauline Letters.

39 Robbins - Melion, Art Visual Exegesis.

40 Youversion, <https://www.youversion.com/>; GloBible, <https://globible.com/>.

41 See Hutchings, "E-reading and the Christian Bible"; Hutchings, "Design and the digital Bible".

42 Gisel, "Apocryphes et canon", p. 230.

43 Bradbury, Fahrenheit 45.
} 